\title{
PENGUKURAN INDEKS KEPUASAN PELANGGAN UNTUK PENINGKATAN KUALITAS LAYANAN
}

\author{
Iva Nurdiana Nurfarida \\ Email : ivanurdiana@unikama.ac.id
}

\begin{abstract}
Abstrak : Customer satisfaction index (CSI) can be used by companies as a measure of the level of customer satisfaction. CSI also be used to compare the performance of products/services with competitors. CSI measurement results can be used to set a strategy to improve the quality of services in order to increase customer satisfaction in the future. Some CSI measurement model has been applied in previous studies, but all have the same focus, comparing the value to the customer expectations. This research use ImportancePerformance (IP) Analysis model to measure the level of customer satisfaction of PDAM Malang Regency. IP-Analysis will give information about elements are a priority, what elements need to be maintained, the element that is not a priority to be addressed, and that high last element that has been good, but not an important element for customers. The results showed that the priority of the elements that must be addressed by PDAM Malang Regency to improve customer satisfaction is about the terms of service, fairness in service, as well as courtesy and hospitality.
\end{abstract}

Keywords: Customer Satisfaction Index, service quality, ImportancePerformance Analysis

\section{PENDAHULUAN}

Pelayanan publik adalah segala kegiatan pelayanan yang dilaksanakan oleh penyelenggara pelayanan publik sebagai pemenuhan kebutuhan penerima pelayanan maupun pelaksana ketentuan peraturan perundang-undangan (SK Menpan No. 63/KEP/M.PAN/2003). Sejak ditetapkannya Undang-Undang No 25 tahun 2009 Tentang Pelayanan Publik, Perusahaan Daerah Air Minum (PDAM) Kabupaten Malang sebagai suatu instansi yang bergerak dalam bidang pelayanan jasa air minum dituntut untuk meningkatkan pelayanan terhadap masyarakat dalam hal ini pelanggan. Selanjutnya dijelaskan lebih rinci dalam Kepmenpan No. $63 \mathrm{Th}$ 2003 Tentang Pedoman Umum Penyelenggaraan Pelayanan Publik. Peningkatan layanan ini harus segera diimplementasikan dengan cara menyusun strategi pelayanan prima agar masyarakat umumnya merasa puas dengan pelayanan yang diberikan. PDAM sebagai perusahaan daerah yang merupakan bagian dari birokrasi pemerintah daerah yang dituntut pengembangan kinerja yang kompetitif seiring dengan perubahan trend globalisasi akhir-akhir ini. Upaya peningkatan kinerja masih mengalami banyak permasalahan yang harus segera diperbaiki, terutama menyangkut keberadaan dan penerapan sistem dan lembaga birokrasi pemerintah yang masih belum sepenuhnya mampu mengembangkan sistem yang

Iva Nurdiana Nurfarida, adalah Dosen Prodi Manajemen FEB Universitas Kanjuruhan Malang 
136 MODERNISASI, Volume 11, Nomor 2, Juni 2015

adaftif terhadap dinamika masyarakat; mengadopsi nilai-nilai baru yang relevan dari dunia bisnis untuk memperbaiki kinerja pelayanan publik. Layanan yang diberikan masih belum optimal, ditunjukkan dari hasil Indeks Kepuasan Pelanggan PDAM tahun 2013 masih disekitar 80\% (Kategori Baik).

Kualitas pelayanan pelanggan PDAM mencakup aspek kualitas, kuantitas dan kontinuitas pelayanan penyediaan air minum, pelayanan sambungan baru, pelayanan pembacaan meter, pelayanan penerimaan pembayaran rekening pelayanan penerimaan pengaduan dan upaya penyelesaian pengaduan. Ukuran keberhasilan penyelenggaraan pelayanan ditentukan oleh tingkat kepuasan penerima pelayanan (masyarakat). Kepuasan pelanggan dicapai apabila pelanggan memperoleh pelayanan sesuai dengan yang dibutuhkan (harapan). Oleh karena itu Perusahaan Daerah Air Minum (PDAM) Kabupaten Malang sebagai instansi publik perlu secara terus menerus meningkatkan kepuasan pelanggan, dengan mengetahui apa harapan dari pelanggan dibandingkan dengan layanan yang telah diberikan.

PDAM Kabupaten Malang sebagai perusahaan daerah yang memberikan layanan air bersih kepada masyarakat, harus memiliki strategi pelayanan prima agar masyarakat umumnya merasa puas dengan pelayanan yang diberikan. Penyusunan strategi tersebut diawali dengan pengukuran Indeks Kepuasan Masyarakat (IKM) terhadap layanan PDAM. Salah satu fungsi dari indeks kepuasan masyarakat adalah mengukur seberapa tinggi tingkat kepuasan masyarakat terhadap layanan yang telah diterima dari PDAM. Kelemahan dari IKM adalah hanya mengukur tingkat kepuasan masyarakat, selanjutnya dirumuskan strategi apa yang bisa diambil oleh manajemen untuk meningkatkan layanan. Pengukuran IKM belum mampu memberikan informasi aspek layanan apa yang menjadi prioritas penting untuk ditingkatkan karena masih dibawah harapan masyarakat, aspek apa yang sudah melebihi harapan pelanggan PDAM. Artikel ini akan menjawab beberapa pertanyaan tentang 1) bagaimana kepuasan masyarakat terhadap layanan PDAM Kabupaten Malang; 2) bagaimana harapan masyarakat terhadap layanan PDAM Kabupaten Malang; 3) bagaimana kesenjangan antara harapan pelanggan dengan kinerja layanan PDAM Kabupaten Malang.

\section{TINJAUAN PUSTAKA}

\section{Kepuasan Pelanggan}

Kepuasan pelanggan adalah tingkat perasaan seseorang setelah membandingkan kinerja (atau hasil) yang ia rasakan dibandingkan dengan harapannya. kepuasan pelanggan adalah perasaan senang atau kecewa yang muncul setelah membandingkan antara persepsi atau kesannya terhadap kinerja atau hasil suatu produk dan harapan-harapannya. Jika kinerja berada di bawah harapan pelanggan tidak puas. Jika kinerja melampaui harapan, pelanggan puas. Jika kinerja melebihi harapan, pelanggan amat puas atau senang (Kotler, 2000). Satisfaction is the customer's fullfilment response. It is a judgement that a product or service feature, or the product or service itself, provides a pleasureable level of consumption related fulfillment (Zeithaml et al, 2001). Kepuasan atau ketidakpuasan akan suatu produk atau jasa sebagai akhir dari suatu proses penjualan memberikan dampak tersendiri kepada perilaku pelanggan akan produk tersebut. Pembentukan sikap dan pola perilaku seorang pelanggan terhadap pembelian dan penggunaan produk atau jasa merupakan hasil dari pengalaman mereka sebelumnya (Lupiyoadi, 2001). 
Kepuasan pelanggan dirumuskan sebagai evaluasi purna beli, dimana persepsi terhadap kinerja alternatif produk atau jasa yang dipilih memenuhi atau melebihi harapan sebelum pembelian. Kepuasan atau ketidakpuasan pelanggan adalah respon pelanggan terhadap evolusi ketidaksesuaian (discinfirmation) yang dirasakan antara harapan sebelumnya dan kinerja aktual produk yang dirasakan bahwa pada persaingan yang semakin ketat ini, semakin banyak produsen yang terlibat dalam pemenuhan kebutuhan dan keinginan konsumen sehingga hal ini menyebabkan setiap badan usaha harus menempatkan orientasi pada kepuasan pelanggan sebagai tujuan utama, antara lain dengan semakin banyaknya badan usaha yang menyatakan komitmen terhadap kepuasan pelanggan dalam pernyataan misi, iklan (Tjiptono, 2000).

Kepuasan pelanggan merupakan representasi dari pengukuran antara kinerja dan kebutuhan pelanggan (Hill et al, 2003), jadi mengukur kepuasan pelanggan melalui pengukuran kualitas layanan. Pelanggan mengungkapkan pandangan mereka tentang layanan dengan memberikan penilaian pada beberapa aspek layanan dengan cara survei, yang dikenal survei kepuasan pelanggan (Eboli dan Mazzula, 2009).

Harapan pelanggan melatarbelakangi mengapa dua organisasi pada jenis bisnis yang sama dapat dinilai berbeda oleh pelanggannya. Dalam konteks kepuasan pelanggan, umumnya harapan merupakan perkiraan atau keyakinan pelanggan tentang apa yang akan diterimanya. Harapan mereka dibentuk oleh pengalaman pembelian dahulu, komentar teman dan kenalannya serta janji dari perusahaan tersebut. Harapan-harapan pelanggan ini dari waktu ke waktu berkembang seiring dengan semakin bertambahnya pengalaman pelanggan. Kepuasan pelanggan didasarkan pada kesesuaian antara harapan pelanggan dengan persepsi yang dirasakan pelanggan dari kinerja produk yang diberikan oleh perusahaan. Kondisi kepuasan pelanggan tercipta apabila persepsi bernilai lebih besar atau sama dengan harapan, sebaliknya kondisi ketidakpuasan terjadi apabila persepsi lebih kecil dari harapan.

Secara konseptual kepuasan pelanggan oleh Tjiptono (2000) digambarkan sebagai berikut:

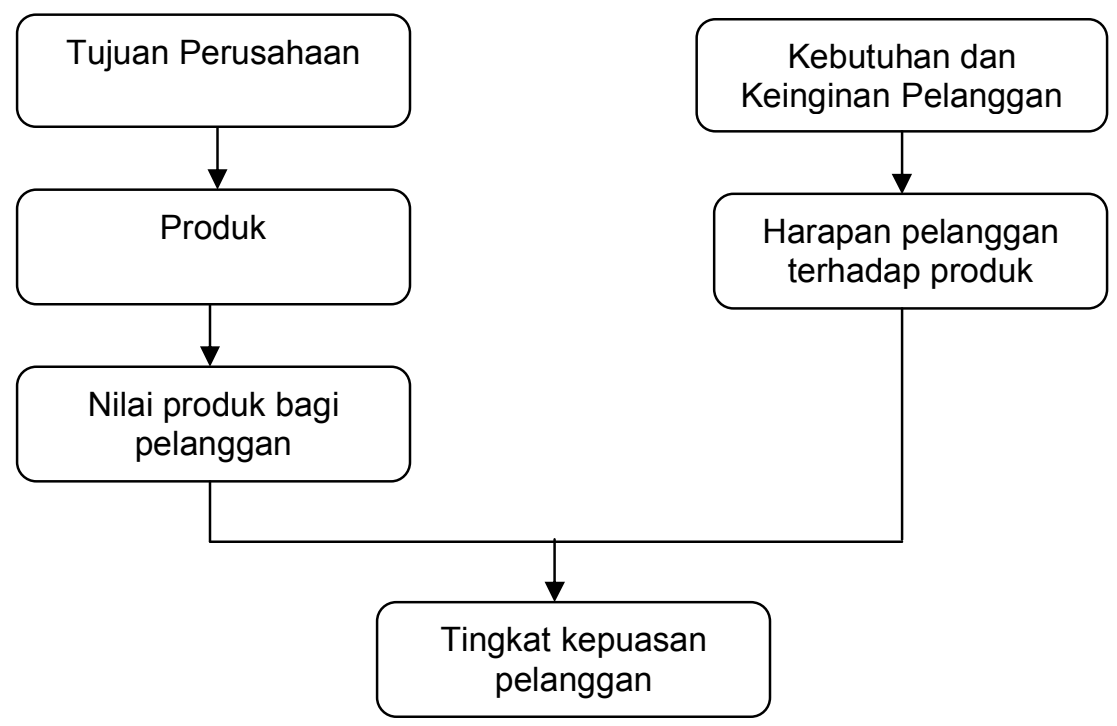

Gambar 1. Konsep Kepuasan Pelanggan 


\section{Indeks Kepuasan Pelanggan (Customer Satisfaction Index)}

Sejumlah negara telah mengembangkan model indeks kepuasan pelanggan untuk barang maupun jasa di negara mereka seperti negara Sweden menetapkan Swedish Customer Satisfaction Barometer (SCSB) pada tahun 1989, America menetapkan The American Customer Satisfaction Index (ACSI) pada tahun 1994; Norway dengan The Norwegian Customer Satisfaction Barometer (NCSB) pada tahun 1996, selanjutnya European Customer Loyalty Index (ECSI), Swiss Index of Customer Satisfaction (SWICS) (Johnson et al, 2001, Eboli dan Mazulla, 2008). Model pengukuran kepuasan ini juga diikuti oleh negara-negara lain seperti Korean Customer Satisfaction Index (KCSI) (Yong-Jae Park et al., 2008; Kim, K.J. et al., 2007), Malaysian Customer Satisfaction Index (MCSI) (Abdullah et al., 2001), termasuk Brazil, Argentina, Mexico, Canada, Australia, Hong Kong and beberapa negara seperti Taiwan termasuk Indonesian Customer Satisfaction Index (ICSI).

Bagi perusahaan, CSI dapat digunakan untuk pengukuran kepuasan pelanggan terhadap kinerja suatu produk. CSI juga bisa digunakan untuk membandingkan produk dengan para kompetitor. Selain indeks kepuasan setiap produk, juga bisa dihitung indeks kepuasan industri (sekumpulan produk sejenis).

Pengukuran tingkat kepuasan pelanggan pada dasarnya membandingkan antara kinerja produk atau jasa dengan harapakan pelanggan, semakin tinggi harapan pelanggan dipenuhi, maka tingkat kepuasan pelanggan semakin tinggi. Pengukuran kepuasan pelanggan melalui survey dapat dilakukan dengan berbagai cara, di antaranya (Kotler, 2000):

a. Directly reported satisfaction

Pengukuran dilakukan secara langsung melalui pertanyaan terkait dengan indikator-indikator kepuasan pelanggan, selanjutnya pelanggan diminta untuk memberikan tanggapan mulai sangat tidak puas, tidka puas, netral, puas, sangat puas.

b. Derived dissatisfaction

Pengukuran dilakukan dengan mengajukan pertanyaan yang menyangkut harapan pelanggan terhadap atribut.

c. Problem analysis

Pelanggan yang dijadikan responden diminta untuk mengungkapkan dua hal pokok yaitu:

1) Masalah-masalah yang mereka hadapi berkaitan dengan penawaran dari perusahaan, dan

2) Saran-saran untuk melakukan perbaikan.

d. Importance performance (I-P) Analysis

Metode ini responden diminta untuk me-rangking berbagai elemen dari penawaran berdasarkan arti penting elemen.

Beberapa model pengukuran indeks kepuasan pelanggan menetapkan indikator berbeda dalam pengukuran kepuasan pelanggan. The American Customer Satisfaction Index (ACSI) menggunakan konstruk perceived quality, customer expectations, perceived value, overall customer satisfaction, customer complaints, customer loyalty dalam pengukuran indeks kepuasan pelanggan (Fornell et al, 1996; Terblanche, 2005; Serenco, 2011). European Customer Loyalty Index (ECSI) menggunakan 6 konstruk meliputi customer expectations, perceived quality, perceived value, customer satisfaction, image (Bayol, et al., 2000; O'Loughlin and G. Coenders, 2004). Swiss Index of Customer Satisfaction (SWICS) menggunakan 
konstruk customer satisfaction, customer dialogue, customer loyalty dalam pengukuran indeks kepuasan pelanggan (Bruhn and Grund, 2000). Canadian CSI menggunakan konstruk perceived quality, customer expectations, perceived value, customer satisfaction, customer complaints, price tolerance, repurchase likelihood dalam pengukuran Indeks kepuasan pelanggan (Turel and Serenko, 2006)

Eboli dan Mazzula (2009) menggunakan model Heterogeneous Customer Satisfaction Index, untuk pengukuran kepuasan pelanggan. Indeks ini merupakan modifikasi dari pengukuran indeks kepuasan pelanggan tradisional yang disebut corrected importance weight dengan memberikan bobot berbeda pada masingmasing aspek yang diukur sehingga memungkinkan mengukur aspek yang menyebabkan kepuasan/ketidakpuasan pelanggan, dan identifikasi strategi untuk meningkatkan kualitas pelayanan.

Hasil penelitian di Korea menunjukkan tingkat kepuasan pelanggan di Korea terhadap layanan provider telekomunikasi lebih rendah dari harapan pelanggan. Pengukuran tingkat kepuasan pelanggan berkaitan dengan layanan baru dan mengidentifikasi prioritas dalam strategi peningkatan kualitas melalui analisis Importance-Performance (IP) (Young-Jae et al, 2008). Penelitian Setiawan (2014) menunjukkan bahwa konstruk perceived quality, perceived value dan customer expectation merupakan konstruk yang mempengaruhi kepuasan pelanggan minyak goreng di Bogor.

Pengukuran kepuasan pelanggan khusus untuk pelayanan publik di Indonesia telah diatur dalam Keputusan Menteri Pendayagunaan Aparatur Negara No. Kep./25/M.PAN/2/2004, dimana terdapat 14 unsur sebagai unsur minimal yang harus ada sebagai dasar pengukuran indeks kepuasan masyarakat, yaitu:

1. Prosedur pelayanan, yaitu kemudahan tahapan pelayanan yang diberikan kepada masyarakat dilihat dari sisi kesederhanaan alur pelayanan;

2. Persyaratan Pelayanan, yaitu persyaratan teknis dan administratif yang diperlukan untuk mendapatkan pelayanan sesuai dengan jenis pelayanannya;

3. Kejelasan petugas pelayanan, yaitu keberadaan dan kepastian petugas yang memberikan pelayanan (nama, jabatan serta kewenangan dan tanggung jawabnya);

4. Kedisiplinan petugas pelayanan, yaitu kesungguhan petugas dalam memberikan pelayanan terutama terhadap konsistensi waktu kerja sesuai ketentuan yang berlaku;

5. Tanggung jawab petugas pelayanan, yaitu kejelasan wewenang dan tanggung jawab petugas dalam penyelenggaraan dan penyelesaian pelayanan;

6. Kemampuan petugas pelayanan, yaitu tingkat keahlian dan ketrampilan yang dimiliki petugas dalam memberikan/menyelesaikan pelayanan kepada masyarakat;

7. Kecepatan pelayanan, yaitu target waktu pelayanan dapat diselesaikan dalam waktu yang telah ditentukan oleh unit penyelenggara pelayanan;

8. Keadilan mendapatkan pelayanan, yaitu pelaksanaan pelayanan dengan tidak membedakan golongan/status masyarakat yang dilayani;

9. Kesopanan dan keramahan petugas, yaitu sikap dan perilaku petugas dalam memberikan pelayanan kepada masyarakat secara sopan dan ramah serta saling menghargai dan menghormati;

10. Kewajaran biaya pelayanan, yaitu keterjangkauan masyarakat terhadap besarnya biaya yang ditetapkan oleh unit pelayanan; 
140 MODERNISASI, Volume 11, Nomor 2, Juni 2015

11. Kepastian biaya pelayanan, yaitu kesesuaian antara biaya yang dibayarkan dengan biaya yang telah ditetapkan;

12. Kepastian jadwal pelayanan, yaitu pelaksanaan waktu pelayanan, sesuai dengan ketentuan yang telah ditetapkan;

13. Kenyamanan lingkungan, yaitu kondisi sarana dan prasarana pelayanan yang bersih, rapi, dan teratur sehingga dapat memberikan rasa nyaman kepada penerima pelayanan;

14. Keamanan Pelayanan, yaitu terjaminnya tingkat keamanan lingkungan unit penyelenggara pelayanan ataupun sarana yang digunakan, sehingga masyarakat merasa tenang untuk mendapatkan pelayanan terhadap resikoresiko yang diakibatkan dari pelaksanaan pelayanan.

\section{METODE}

\section{Sampel penelitian}

Penelitian ini dilakukan untuk mengukur tingkat kepuasan pelanggan PDAM Kabupaten Malang, mengukur kepuasan pelanggan pada 25 unit layanan, dengan populasi sebanyak 78.557 pelanggan aktif. Teknik pengambilan sampel menggunakan metode Proportional Stratified Random Sampling, yaitu pengambilan sampel berdasarkan strata didasarkan pada kelompok pelanggan, jumlah sampel masing-masing kelompok pelanggan diambil secara proporsional. Selanjutnya pemilihan sampel untuk masing-masing strata dilakukan secara random. Penentuan jumlah Sampel mengadopsi tabel Krejcie \& Morgan, bahwa jumlah populasi sampai 75 ribu maka digunakan sampel sebanyak 384 .

\section{Variabel Penelitian}

Variabel dalam penelitian ini adalah kepuasan pelanggan, yaitu tanggapan responden terhadap layanan yang diterima dari PDAM Kabupaten Malang. Pengukuran kepuasan pelanggan menggunakan aspek sumberdaya manusia (layanan) didasarkan pada Keputusan Meneteri Pendayagunaan Aparatur Negara No. Kep/25/M.PAN/2/2004 tentang Pedoman Umum Penyusunan Indeks Kepuasan Masyarakat Unit Pelayanan Instansi Pemerintah, dimana pengukuran kepuasan masyarakat menggunakan 14 indikator:

1. Prosedur pelayanan;

2. Persyaratan Pelayanan;

3. Kejelasan petugas pelayanan;

4. Kedisiplinan petugas pelayanan;

5. Tanggung jawab petugas pelayanan;

6. Kemampuan petugas pelayanan;

7. Kecepatan pelayanan;

8. Keadilan mendapatkan pelayanan;

9. Kesopanan dan keramahan petugas

10. Kewajaran biaya pelayanan;

11. Kepastian biaya pelayanan;

12. Kepastian jadwal pelayanan;

13. Kenyamanan lingkungan;

14. Keamanan Pelayanan. 
Pengumpulan data dalam penelitian ini menggunakan kuesioner, yang disusun dalam bentuk Skala Likert yang dimodifikasi menjadi 4 skala, yaitu skala mulai dari Tidak puas (1) sampai Sangat Puas (4).

\section{Teknik Analisis Data}

Analisis data yang digunakan untuk mengukur Kepuasan Pelanggan PDAM adalah Importance-Performance Analysis (I-P Analysis) atau dikenal juga dengan istilah Gap Analysis (Analisis Kesenjangan). I-P Analysis digunakan untuk mengukur seberapa besar kesenjangan antara tingkat kepentingan (harapan pelanggan) dengan kenyataan (kualitas layanan PDAM). Analisis kesenjangan untuk mengetahui urutan prioritas aspek-aspek layanan yang menentukan kepuasan pelanggan menggunakan Diagram Kartesius. Diagram Kartesius merupakan suatu diagram yang dibagi menjadi empat kuadran, yang dibatasi oleh dua buah garis horisontal dan vertikal pada titik koordinat $\mathrm{X}$ dan $\mathrm{Y}$, dimana $\mathrm{X}$ adalah rata-rata skor tingkat kenyataan (kinerja layanan), sedangan $\mathrm{Y}$ adalah rata-rata skor tingkat kepentingan (harapan pelanggan).

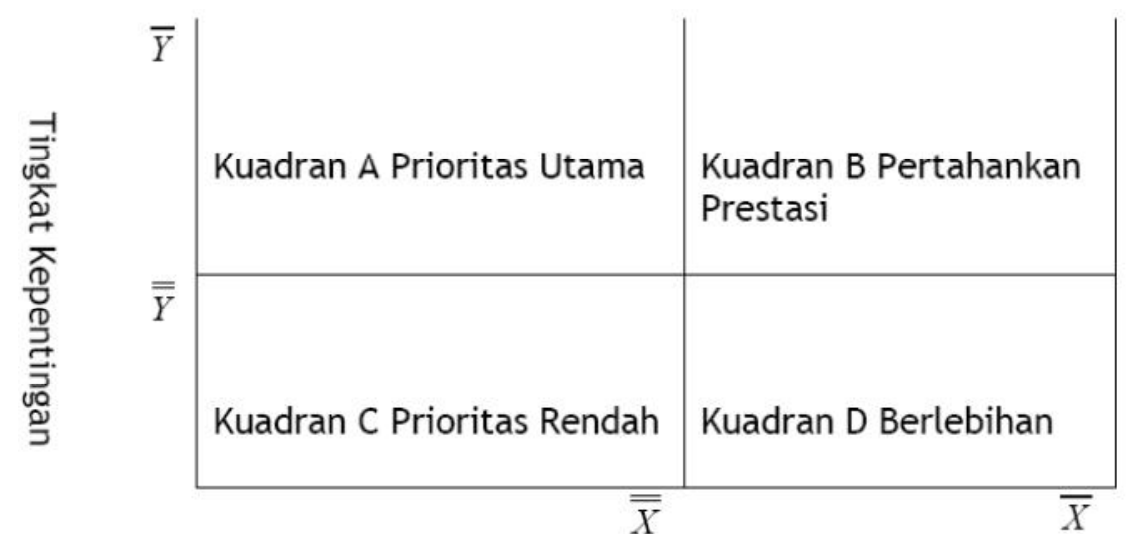

\section{Kenyataan Kinerja}

Gambar 2. I-P Analysis

Rumus untuk menghitung rata-rata skor harapan dan kinerja layanan adalah sebagai berikut:

$$
\overline{\bar{X}}=\frac{\sum_{i=1}^{N} \bar{X} i}{K} \quad \overline{\bar{Y}}=\frac{\sum_{i=1}^{N} \overline{Y i}}{K}
$$

Keterangan:

$\mathrm{N}=$ Jumlah responden

$\mathrm{K}=$ jumlah butir pernyataan 
142 MODERNISASI, Volume 11, Nomor 2, Juni 2015

\section{PEMBAHASAN}

\section{Kualitas Layanan}

Berdasarkan hasil pengukuran persepsi kualitas layanan di PDAM Kabupaten Malang dengan menggunakan 14 indikator dapat diketahui tingkat kualitas layanan menurut para pelanggan yang menjadi sampel.

Tabel 1. Kualitas layanan

\begin{tabular}{|c|l|c|c|}
\hline No & \multicolumn{1}{|c|}{ Unsur Pelayanan } & Kinerja & Harapan \\
\hline 1 & Prosedur pelayanan & 3,298 & 3,522 \\
\hline 2 & Persyaratan pelayanan & 3,109 & 3,539 \\
\hline 3 & Kejelasan petugas pelayanan & 3,298 & 3,537 \\
\hline 4 & Kedisiplinan petugas pelayanan & 3,295 & 3,530 \\
\hline 5 & Tanggung jawab petugas pelayanan & 3,283 & 3,532 \\
\hline 6 & Kemampuan petugas pelayanan & 3,292 & 3,535 \\
\hline 7 & Kecepatan petugas pelayanan & 3,279 & 3,532 \\
\hline 8 & Keadilan mendapatkan pelayanan & 3,203 & 3,532 \\
\hline 9 & Kesopanan dan keramahan petugas & 3,205 & 3,537 \\
\hline 10 & Kewajaran biaya pelayanan & 3,205 & 3,450 \\
\hline 11 & Kepastian biaya pelayanan & 3,233 & 3,474 \\
\hline 12 & Kepastian jadwal pelayanan & 3,281 & 3,502 \\
\hline 13 & Kenyamanan lingkungan & 3,205 & 3,506 \\
\hline 14 & Keamanan pelayanan & 3,292 & 3,513 \\
\hline & Rerata & $\mathbf{3 , 2 4 8}$ & $\mathbf{3 , 5 1 7}$ \\
\hline & Nilai Dasar & $\mathbf{2 5}$ & \\
\hline & Indeks Kepuasan & $\mathbf{B A I K}$ & \\
\hline & Kategori & & \\
\hline
\end{tabular}

Sumber: Data diolah.

Nilai Indek Kepuasan Pelanggan PDAM Kabupaten Malang secara keseluruhan dari 14 unsur yang dinilai masuk kategori Baik dengan nilai IKM 81,208 . Adapun unsur yang dinilai paling baik dalam pelayanan adalah adanya kejelasan persyaratan dalam layanan, sedangkan unsur yang dinilai paling rendah dalam pelayanan PDAM adalah masalah kewajaran biaya. Kewajaran dipersepsikan paling rendah disebabkan masyarakat rata-rata memiliki sumber pemenuhan kebutuhan air tidak hanya dari PDAM, misalnya sumber air swadaya maupun sumur, sehingga manakala menerima layanan PDAM dan harus mengeluarkan sejumlah biaya dianggap mahal.

Selanjutnya masing-masing unsur jika dibandingkan dengan rerata, dari 14 unsur masih terdapat 6 unsur yang berada di bawah rerata meliputi: persyaratan layanan, keadilan mendapatkan layanan, kesopanan dan keramahan petugas, kewajaran biaya, kepastian biaya, dan kenyamanan lingkungan. Keenam unsur tersebut harus menjadi perhatian bagi PDAM Kabupaten Malang untuk ditingkatkan, dalam rangka peningkatan layanan dan kepuasan pelanggan. 


\section{Importance-Performance (I-P) Analysis}

Hasil analisis kesenjangan (I-P Analysis) dengan membandingkan antara kinerja dan harapan pelanggan terhadap layanan, dapat disajikan pada gambar berikut:

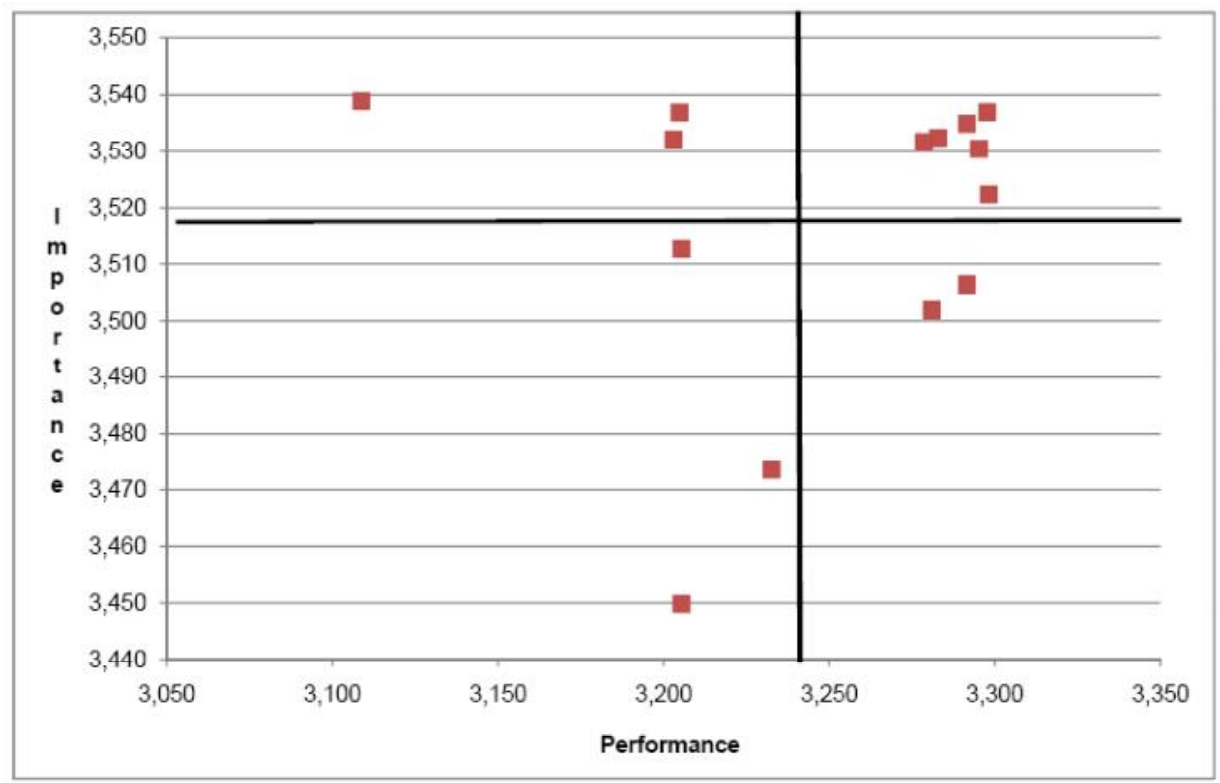

Gambar 3. I-P Analysis

Berdasarkan Importance-Performance Analysis tersebut dapat diketahui seberapa besar kesenjangan antara tingkat kepentingan (importance) dengan kenyataan (performance) layanan.

\section{Kuadran A. Prioritas Utama}

Merupakan unsur-unsur layanan yang memiliki arti penting (importance) tinggi bagi pelanggan, namun kinerja layanan (performance) masih di bawah rerata. Beberapa unsur layanan yang masuk dalam prioritas utama untuk ditingkatkan adalah:

1. Persyaratan layanan

2. Keadilan mendapatkan layanan

3. Kesopanan dan keramahan petugas

Ketiga unsur tersebut mutlak untuk segera ditingkatkan karena pelanggan menganggap belum puas terhadap ketiga unsur layanan tersebut padahal ketiga unsur tersebut dianggap penting bagi pelanggan untuk meningkatkan kepuasan.

\section{Kuadran B. Pertahankan Prestasi}

Merupakan unsur-unsur layanan yang memiliki arti penting (importance) tinggi bagi pelanggan, dan kinerja layanan (performance) yang diterima sudah baik. Beberapa unsur layanan yang masuk dalam kuadran pertahankan prestasi adalah:

1. Prosedur layanan 
144 MODERNISASI, Volume 11, Nomor 2, Juni 2015

2. Kejelasan petugas layanan

3. Kedisiplinan petugas layanan

4. Tanggungjawab petugas layanan

5. Kemampuan petugas pelayanan

6. Kecepatan petugas pelayanan

Keenam unsur tersebut harus tetap dipertahankan oleh PDAM Kabupaten Malang karena pelanggan menganggap unsur-unsur tersebut penting untuk meningkatkan kepuasan pelanggan, dan pelanggan sudah puas terhadap unsur layanan tersebut.

\section{Kuadran C. Prioritas Rendah}

Merupakan unsur-unsur layanan yang memiliki arti penting (importance) rendah bagi pelanggan, sejalan kinerja layanan (performance) yang dicapai juga rendah. Beberapa unsur layanan yang masuk dalam kuadran prioritas rendah adalah:

1. Kewajaran biaya layanan

2. Kepastian biaya layanan

3. Kenyamanan lingkungan layanan

Ketiga unsur tersebut untuk tidak menjadi prioritas dalam upaya peningkatan kepuasan pelanggan, karena memiliki arti penting bagi pelanggan tidak tinggi, demikian pula kepuasan pelanggan terhadap unsur-unsur ini juga tidak tinggi. Hal ini menunjukkkan bahwa sebenarnya para pelanggan sudah menyadari bahwa harga yang ditetapkan PDAM sudah memperhitungkan banyak hal, hanya saja para pelanggan menginginkan kalau bisa PDAM sebagai pelayanan publik bisa mengambil kebijakan menyediakan harga air minum yang lebih murah bagi masyarakat.

\section{Kuadran C. Berlebihan}

Merupakan unsur-unsur layanan yang memiliki arti penting (importance) rendah bagi pelanggan, namun kinerja layanan (performance) yang dicapai sudah tinggi. Beberapa unsur layanan yang masuk dalam kuadran ini adalah:

1. Kepastian jadwal layanan

2. Keamanan layanan

Kedua unsur pelayanan tersebut dianggap sudah melampai harapan pelanggan, walaupun sebenarnya pelanggan tidak terlalu menuntut layanan kedua unsur tersebut, karena jadwal layanan sudah sesuai dengan ketentuan, demikian pula keamanan layanan termasuk keakuratan data, pelanggan sangat percaya terhadap kedua unsur tersebut.

\section{KESIMPULAN}

Berdasarkan Importance-Performance Analysis (I-P Analysis) terhadap 14 unsur layanan dapat ditemukan bahwa dengan melakukan I-P Analysis dapat ditentukan unsur-unsur apa yang menjadi prioritas, unsur apa yang perlu dipertahankan, unsur yang tidak menjadi prioritas untuk segera dibenani, dan yang terakhiri unsur yang sudah baik namun tidak menjadi unsur yang penting bagi pelanggan. Adapun prioritas unsur-unsur yang harus segera dibenahi oleh PDAM Kabupaten Malang untuk meningkatkan kepuasan pelanggan adalah perihal persyaratan layanan, keadilan dalam memberikan layanan, serta kesopanan dan 
keramahan petugas. Penetapan persyaratan layanan menjadi penting bagi perusahaan yang memberikan layanan kepada pelanggan, karena persyaratan adalah kunci awal dari suatu prosedur layanan untuk bisa diproses pada layanan berikutnya. Prinsip layanan yang baik adalah adanya komunikasi yang baik antara pemberi pelayanan dan penerima layanan, sehingga kesopanan, keramahan petugas menjadi sangat penting. Keterbatasan penelitian ini hanya dilakukan pada satu perusahaan saja, kepada peneliti selanjutnya direkomendasikan untuk menambah pada perusahaan publik yang memberikan layanan kepada masyarakat seperti Perusahaan Listrik Negara, Perusahaan Kereta Api, Telkom dalam satu penelitian.

\section{DAFTAR PUSTAKA}

Abdullah, M., Husain, N., El-Nassir, AD., 2001, Theory And Development Of National Customer Satisfaction Index: The Malaysian Index Of Customer Satisfaction, The 6 th TQM Conggres, Saint Petersburg.

Bayol, M.P., Foye, A., Tellier, C. and Tenenhaus, M.. 2000, Use of PLS Path Modeling to estimate the European Consumer Satisfaction Index (ECSI) Model. Statistica Applicata. 12 (3): 361-375

Bruhn, M and Grund, M.A. 2000, Theory, Development, and Implementation of National Customer Satisfaction Indices: The Swiss Index of Customer Satisfaction (SWICS), Total Quality Management, vol. 11, no. 7, pp. S1017-S1028.

Eboli, L. and Mazzulla, G., 2009, A New Customer Satisfaction Index for Evaluating Transit Service Quality, Journal of Public Transportation, Vol. 12, No. 3.

Eboli, L., and G. Mazzulla. 2008a. An SP Experiment for Measuring Service Quality in Public Transport. Transportation Planning and Technology 31(5): 509-523.

Eboli, L., and G. Mazzulla. 2008b. Willingness-to-Pay of Public Transport Users for Improvement in Service Quality. European Transport 38: 107-118.

Fornell, C., Johnson, M. D., Anderson, E. W., Cha, J., \& Everitt Bryant, B. 1996. Growing the trust relationship. Journal of Marketing, 60(4), 7-18

Hill N., G. Brierley, and R. MacDougall. 2003. How to Measure Customer Satisfaction. Gower Publishing, Hampshire.

Johnson, Michael D. Anders Gustafsson, dan Tor Wallin Andreassen. (2001), The Evolution and Future of National Customer Satisfaction Index Models. Journal of Economic Psychology. Vol 22: 217-245

Keputusan Menteri Pemberdayaan Aparatur Negara No. 63/KEP/M.PAN/7/2003 tentang Pedoman Umum Penyelenggaraan Pelayanan Publik. 
Keputusan Menteri Pemberdayaan Aparatur Negara No. KEP/25/M.PAN/2/2004 tentang Pedoman Umum Penyusunan Indeks Kepuasan Masyarakat Unit Pelayanan Instansi Pemerintah.

Kim, K.J. et al., 2007. The Impact of Network Service Performance on Customer Satisfaction and Loyalty: High-Speed Internet Service Case in Korea, Expert Systems with Applications, Vol. 32, pp. 822-831.

Kotler, Philip. 2000. Manajemen Pemasaran: Analisis, Perencanaan, Implementasi dan pengendalian. (Alihbahasa Arcella Ariwati Hermawan), Jakarta: Salemba Empat

Lupiyoadi, Rambat, 2001, Manajemen Pemasaran Jasa, Edisi 1, Penerbit Salemba Empat. Jakarta

O'Loughlin and G. Coenders, "Estimation of European Customer Satisfaction Index: Maximum Likelihood versus Partial Least Squares: Application to Postal Service," Total Quality Management, Vol. 15, No. 9-10, pp. 12311255.

Serenko, A. 2011, Student satisfaction with Canadian music programmes: the application of the American Customer Satisfaction Model in higher education, Assessment \& Evaluation In Higher Education, 36, 3, pp. 281299.

Setiawan, Budi. 2014, Customer Satisfaction Index Model on Three Level Of Socioeconomic Status In Bogor Case Study: Customer Satisfaction on Branded Cooking Oil Product, Asean Marketing Journal, Vol.VI, No. 1.

Terblanche, Nic S. 2005. A Study of Two Customer Retention Measures: The American Customer Satisfaction Index And The Conversion Model. ANZMAC Conference: Relationship Marketing (Consumer). 1: 50 - 65

Tjiptono, Fandy 2000, Pemasaran Jasa, Penerbit: Andi offset, Yogyakarta

Turel and Serenko, 2006, Satisfaction with Mobile Services in Canada: An Empirical Investigation, Telecommunications Policy, vol. 30, no. 5-6, pp. 314-331.

Undang-Undang No 25 tahun 2009 Tentang Pelayanan Publik

Yong-Jae Park, Pil-Sun Heo, and Myung-Hwan Rim, 2008. Measurement of a Customer Satisfaction Index for Improvement of Mobile RFID Services in Korea, ETRI Journal, Volume 30 (5).

Zeithaml et al., 1996. Measuring the quality of relationship in customer service: An empirical study. European. Journal of Marketing 